\title{
Water-rock interaction of the Jilh and Tawil aquifers in the Wadi Sirhan Basin, NW Saudi Arabia
}

\author{
Fahad Souid ${ }^{1, *}$, Peter Birkle ${ }^{2}$, and Fred Worrall $^{3}$ \\ ${ }^{1}$ Groundwater Division, Saudi Aramco, 31311 Dhahran, Saudi Arabia \\ ${ }^{2}$ EXPEC Advanced Research Centre, Saudi Aramco, 31311 Dhahran, Saudi Arabia \\ ${ }^{3}$ Earth Sciences Department, Durham University, DH1 3LE Durham, United Kingdom
}

\begin{abstract}
A total of 79 groundwater samples from the Upper SilurianLower Devonian Tawil and Triassic Jilh aquifers in NW Saudi Arabia were analysed for hydrochemical and strontium isotopic composition. A sequential extraction and ${ }^{87} \mathrm{Sr} /{ }^{86} \mathrm{Sr}$ analysis were conducted on 32 cutting samples from the groundwater host rocks and the underlying shale bed. The chemical composition of the groundwater was distinct from that of the host rock lithologies in terms of elemental abundance (i.e., $\mathrm{Na}^{+}$was dominant in the groundwater and $\mathrm{K}$ and $\mathrm{Ca}$ were the main constituents of the aquifer units). Principal component analysis (PCA) of water samples showed a positive loading of $\mathrm{Na}^{+}$and negative loadings of $\mathrm{Ca}^{2+}$ and $\mathrm{SO}_{4}{ }^{2-}$. The replacement of gypsiferous waters by $\mathrm{Na}^{+}$-rich waters is suggested by this ion exchange. The shale rock samples showed $\mathrm{Na}$ to be the dominant chemical constituent. ${ }^{87} \mathrm{Sr} /{ }^{86} \mathrm{Sr}$ ratios of the groundwater $(0.707673$ $0.711577)$ and host rock samples (0.707930-0.712477) suggest that groundwater inherits the $\mathrm{Sr}$ signature of the rock from the exchangeable, carbonate, and the oxides phase, reflecting reducing conditions in Tawil aquifer. The elevated groundwater ${ }^{87} \mathrm{Sr} /{ }^{86} \mathrm{Sr}$ ratios were found in deeper sections of the aquifers, which coincided with the radiogenic ${ }^{87} \mathrm{Sr} /{ }^{86} \mathrm{Sr}$ of the deeper aquifer lithologies and the underlying shale bed.
\end{abstract}

\section{Study Area}

The study area is located in the northwestern part of Saudi Arabia close to the border with Jordan and Iraq, with a total area of $71,225 \mathrm{~km}^{2}$ (Fig. 1). The first aquifer forms part of the Tawil Formation of Upper Silurian-Lower Devonian age. The second aquifer is Jilh, which is composed of Triassic carbonates. Both aquifers overlie the Ordovician-Silurian Qusaiba Member, and are used to supply the region with water. Both aquifers are at similar depth, as the western part of the basin is structurally uplifted, causing the absence of the Tawil aquifer toward the west. At the areas where Tawil aquifer is truncated, Jilh is used as the alternative source of water, since Tawil groundwaters are believed to leak into the Jilh aquifer sediments [1].

\footnotetext{
* Corresponding author: fsouid95@gmail.com
} 


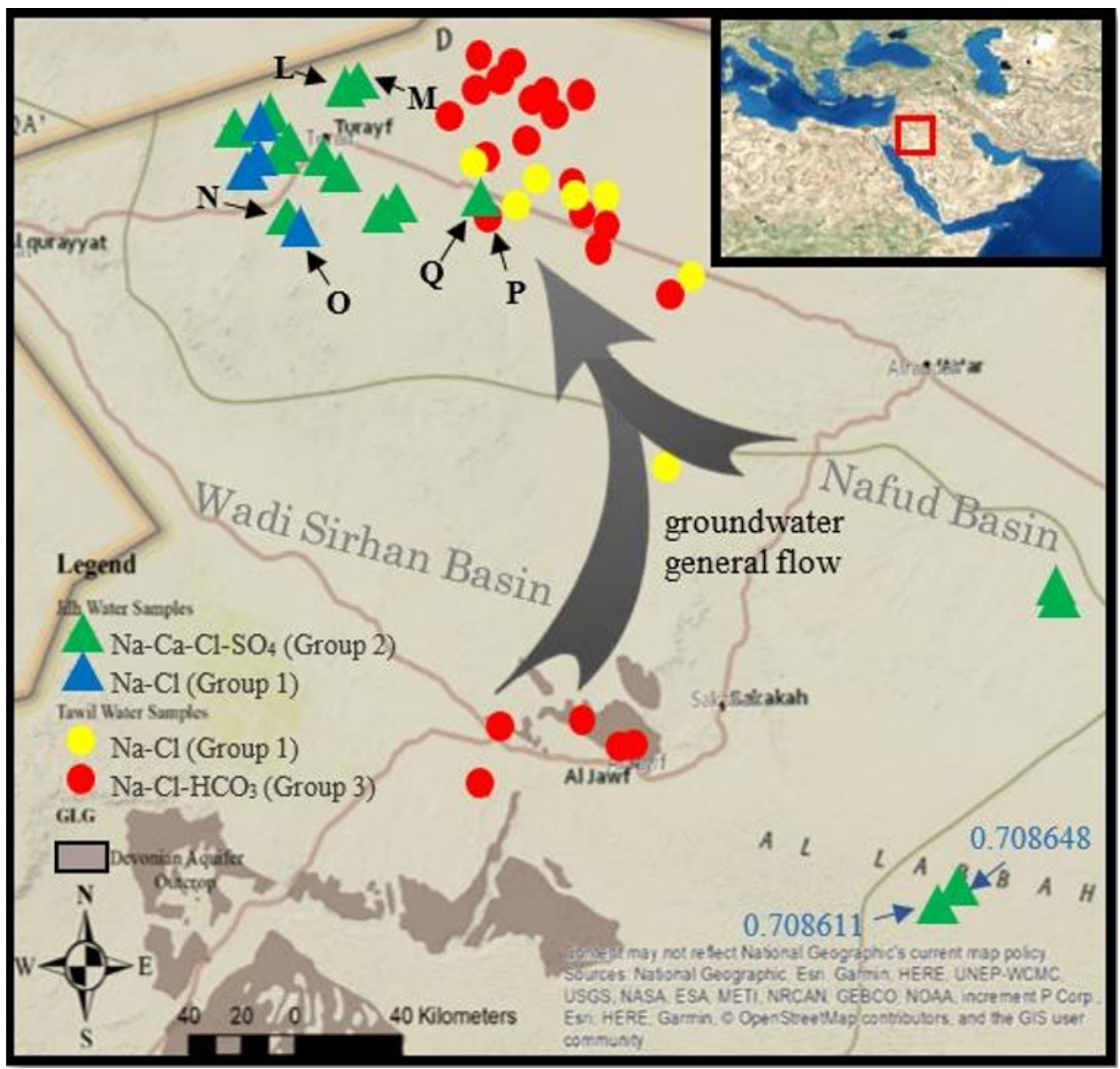

Fig. 1. Study area showing water types of Tawil (circle) and Jilh (triangle) aquifers.

\section{Method}

A total of 79 groundwater samples were collected from water supply wells tapping both aquifers at similar depths, which ranges between 410 and $1100 \mathrm{~m}$ below ground level (Fig. 1). Major cations $\left(\mathrm{Na}^{+}, \mathrm{Ca}^{2+}, \mathrm{Mg}^{2+}\right.$, and $\left.\mathrm{K}^{+}\right)$and trace elements $(\mathrm{Sr}$ and $\mathrm{Ba}$ ) were measured using inductively coupled plasma - optical emission spectrometer (ICP-OES). Major anions were measured using ion chromatography for $\mathrm{Cl}^{-}$and $\mathrm{SO}_{4}{ }^{2-}$, whereas $\mathrm{HCO}_{3}{ }^{-}$was measured using titration technique. The rock samples of both aquifers and the underlying shale bed were collected as cuttings from different depths of the wells during drilling. The cuttings of the rock samples were first washed, then sieved before being crushed and milled to powder using an agate ball mill. Sequential extraction following Tessier's method [2] was conducted on the rock samples, in which the metals $(\mathrm{Na}, \mathrm{Ca}, \mathrm{Mg}, \mathrm{K}, \mathrm{Sr}$, and $\mathrm{Ba})$ in the exchangeable, carbonate, oxide, organic matter, and residual phase were extracted and analysed using ICP-OES. A total of 15 water samples and 10 rock digests were analysed for ${ }^{87} \mathrm{Sr} /{ }^{86} \mathrm{Sr}$ using multi-collector ICP-MS. Piper diagrams and statistical methods, e.g. analysis of variance (ANOVA) and principal component analysis (PCA), were used to identify the main water types and the chemical processes in the groundwater bodies. ANOVA was also used to test the elemental abundances in each phase of the rock samples. 


\section{Results}

Groundwater salinity is relatively low to intermediate with total dissolved solids (TDS) range between $189.2 \mathrm{mg} / \mathrm{L}$ and $3638 \mathrm{mg} / \mathrm{L}$. The analysed groundwater can be classified into three groups (Fig. 2). Most of the water samples belong to Group $1(\mathrm{Na}-\mathrm{Cl})$, which indicates the dominance of alkali constituents $\left(51-71 \% \mathrm{Na}^{+}+\mathrm{K}^{+}\right)$and $71-96 \%$ strong acid (mainly of $\mathrm{Cl}^{-}$) water type. Group 2 shows mixed type of the general $\mathrm{Na}-\mathrm{Cl}$ with $\mathrm{Ca}-\mathrm{Cl}-\mathrm{SO}_{4}$ type (up to $76 \%$ alkaline earth type) and is relatively higher in terms of TDS than Group 1 (Fig. 2). Group 3 is less saline than Group 2 and displays $\mathrm{Na}-\mathrm{Cl}-\mathrm{HCO}_{3}$ water type. A $t$-test showed $\mathrm{SO}_{4}{ }^{2-}$ to be positively correlated to $\mathrm{Ca}^{2+}$ and $\mathrm{Mg}^{2+}$ concentrations in the water, and these correlations are significant at the $99 \%$ probability. The spatial distribution of these chemical groups is illustrated in Fig. 1.

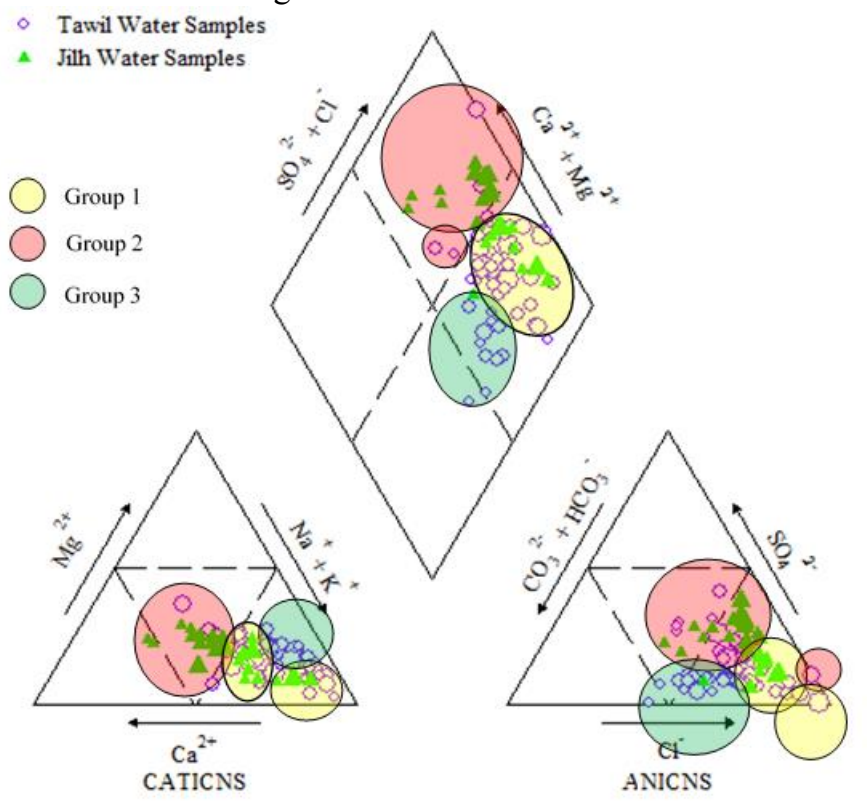

Fig. 2. Piper diagram of groundwater samples from Tawil (circle) and Jilh (triangle) aquifers.

Table 1. PCA for water samples chemical constituents.

\begin{tabular}{|c|c|c|c|}
\hline Variable & PC1 & PC2 & PC3 \\
\hline $\mathrm{Na}^{+}$ & 0.359 & -0.211 & -0.401 \\
\hline $\mathrm{Ca}^{2+}$ & 0.383 & 0.221 & 0.212 \\
\hline $\mathrm{Mg}^{2+}$ & 0.377 & 0.133 & 0.147 \\
\hline $\mathrm{SO}_{4}^{2-}$ & 0.307 & 0.314 & 0.158 \\
\hline $\mathrm{Cl}^{-}$ & 0.397 & -0.118 & -0.157 \\
\hline $\mathrm{TDS}$ & 0.424 & -0.094 & -0.116 \\
\hline $\mathrm{K}^{+}$ & 0.125 & -0.398 & 0.829 \\
\hline
\end{tabular}

The groundwater samples from both aquifers were combined in one PCA since a common hydraulically connected groundwater system is assumed between the Jilh and Tawil Formations, suggested by [1]. PC2 has a high positive loading of $\mathrm{SO}_{4}{ }^{2-}$, correlated positively with $\mathrm{Ca}^{2+}$ and $\mathrm{Mg}^{2+}$, whereas the rest of the variables show negative loadings (Table 1). In terms of rock samples, ANOVA shows $\mathrm{K}$ and $\mathrm{Ca}$ to be the highest constituents 
to fractionate in the exchangeable phase of the aquifer leachates (mean concentrations of 5478 and $1515 \mu \mathrm{g} / \mathrm{g}$, respectively), compared to $\mathrm{Na}$ (average content of $700 \mu \mathrm{g} / \mathrm{g}$ ) based on $95 \%$ probability, whereas the shale leachates are characterised by high concentrations of exchangeable $\mathrm{Na}(10610 \mu \mathrm{g} / \mathrm{g})$. Ca is significantly the highest to leach out in the carbonate phase (average of $15948 \mu \mathrm{g} / \mathrm{g})$, followed by K $(2392 \mu \mathrm{g} / \mathrm{g})$, then $\mathrm{Mg}(768 \mu \mathrm{g} / \mathrm{g})$, at the $95 \%$ probability. Therefore, $\mathrm{Na}$ is not a major constituent of the lithology of both aquifers. The shale samples show higher Na concentrations in the carbonate phase $(867 \mu \mathrm{g} / \mathrm{g})$ compared to average of $105 \mu \mathrm{g} / \mathrm{g} \mathrm{Na}$ in the Tawil and Jilh aquifer rocks.

The groundwater samples from the Jilh and Tawil aquifers show a wide range of ${ }^{87} \mathrm{Sr} /{ }^{86} \mathrm{Sr}$ ratios, which can be divided into three groups. Group I ranges between 0.707673 and 0.707894 (Tawil), Group II between 0.708014 and 0.708648 (Tawil and Jilh), and Group III is more elevated, ranging from 0.710153 up to 0.711577 (Tawil, Fig. 3). The carbonate host rock samples from the Tawil Formation display a similar range of ${ }^{87} \mathrm{Sr} /{ }^{86} \mathrm{Sr}$ to that of Group I and II water samples (0.707930-0.708428), obtained from $\mathrm{Sr}$ in the exchangeable and the oxides phase. The deeper aquifer section in the exchangeable phase shows higher ${ }^{87} \mathrm{Sr} /{ }^{86} \mathrm{Sr}$ ratios $(0.710129-0.712477)$, mimicking that of Group III water samples. The underlying shale formation shows highly radiogenic ${ }^{87} \mathrm{Sr} /{ }^{86} \mathrm{Sr}$ of 0.717278 and 0.719518 from exchangeable $\mathrm{Sr}$ (Fig. 3). ${ }^{87} \mathrm{Sr} /{ }^{86} \mathrm{Sr}$ was measured in aquifer cutting sample in the residual phase, and a value of 0.759395 was obtained.

\section{Discussion}

The correlation between $\mathrm{SO}_{4}{ }^{2-}$ and $\mathrm{Ca}^{2+}$ illustrated by $\mathrm{PC} 2$ in Table 1 suggests either the presence of gypsum layers that are dissolving along the water's evolution pathways (i.e., south to north) or mixing with an influx of gypsiferous waters. Water well $\mathrm{P}$ in Fig. 1 shows elevated $\mathrm{Na}^{+}$and low $\mathrm{SO}_{4}{ }^{2-}$ content ( $\mathrm{Na}-\mathrm{Cl}$ water type), whereas borehole $\mathrm{Q}, 6 \mathrm{~km}$ away, shows higher $\mathrm{Ca}$ and $\mathrm{SO}_{4}{ }^{2-}$ concentrations than $\mathrm{Na}^{+}$(K-Ca-Cl-SO $\mathrm{S}_{4}$, Table 2). This represents an evidence of ion exchange in the groundwater. Borehole $\mathrm{L}$ from Jilh aquifer shows elevated $\mathrm{Na}^{+}$and $\mathrm{Cl}^{-}$content, whereas borehole $\mathrm{M}$ has lower $\mathrm{Na}^{+}$and $\mathrm{Cl}^{-}$content, higher $\mathrm{Ca} / \mathrm{Na}$ ratio compared to that of borehole $\mathrm{L}$, and they are $4.8 \mathrm{~km}$ apart (Table 2). Although within a short lateral distance of $500 \mathrm{~m}$, boreholes $\mathrm{N}$ and $\mathrm{O}$ show different water compositions of Na-Ca-Cl-SO $\mathrm{S}_{4}$ and $\mathrm{Na}-\mathrm{Cl}$, respectively. Borehole $\mathrm{O}$ displays $\mathrm{Na}^{+}$content that is almost 3 times higher than that in borehole $\mathrm{N}$, while the latter has higher $\mathrm{Ca}^{2+}$, almost double that of borehole $\mathrm{O}$ (Table 2).

Table 2. Water samples chemical compositions.

\begin{tabular}{|c|c|c|c|c|c|c|c|c|c|}
\hline \multirow[t]{2}{*}{ Well } & $\mathrm{Na}^{+}$ & $\mathrm{Ca}^{2+}$ & $\mathrm{Mg}^{2+}$ & $\mathbf{K}^{+}$ & $\mathrm{Cl}^{-}$ & $\mathrm{SO}_{4}{ }^{2-}$ & \multirow[t]{2}{*}{ Aquifer } & Distance & Depth \\
\hline & $\mathrm{mg} / \mathrm{L}$ & $\mathrm{mg} / \mathrm{L}$ & $\mathrm{mg} / \mathrm{L}$ & $\mathrm{mg} / \mathrm{L}$ & $\mathrm{mg} / \mathrm{L}$ & $\mathrm{mg} / \mathrm{L}$ & & $\mathrm{m}$ & m \\
\hline $\mathbf{P}$ & 1400 & 175 & 79 & 28 & 2230 & 85 & \multirow[b]{2}{*}{ Tawil } & \multirow[b]{2}{*}{6300} & $415-$ \\
\hline $\mathbf{Q}$ & 220 & 300 & 82 & 634 & 1040 & 388 & & & 765 \\
\hline $\mathbf{L}$ & 1800 & 415 & 152 & 56 & 3390 & 695 & \multirow[b]{2}{*}{ Jilh } & \multirow[b]{2}{*}{4800} & $425-$ \\
\hline M & 420 & 248 & 119 & 36 & 938 & 379 & & & 685 \\
\hline $\mathbf{N}$ & 290 & 247 & 103 & 30 & 830 & 287 & \multirow{2}{*}{ Jilh } & \multirow{2}{*}{500} & $457-$ \\
\hline O & 760 & 138 & 48 & 11 & 1070 & 314 & & & 622 \\
\hline
\end{tabular}

$\mathrm{Ca}^{2+}$ is believed to have been dissolved from evaporites (gypsum $\mathrm{CaSO}_{4} \bullet 2 \mathrm{H}_{2} \mathrm{O}$ ), as high quantities of $\mathrm{Ca}^{2+}$ are found in the exchangeable phase of the aquifers' rock samples. The lithology of the Jilh and Tawil formations are dominated by calcite and dolomitic limestone, as $\mathrm{Ca}^{2+}$ and $\mathrm{Mg}^{2+}$ are the main two elements to fractionate in the carbonate phase, associated with the partial presence of evaporitic sheets. The positive correlation of $\mathrm{Ca}^{2+}$ to $\mathrm{K}^{+}$in the loadings of PC3 negates any ion exchange between the two. $\mathrm{Na}^{+}$ preferentially stays in solution once liberated, unlike $\mathrm{K}^{+}$, which tends to re-adsorb into 
sediments, especially weathered products, e.g., clay [3]. Rather than being inherited from the aquifers' sediments, $\mathrm{Na}^{+}$seems to have been added to the water via a secondary inflow, which exchanges for $\mathrm{Ca}^{2+}$, as seen in the dominating ion-exchange in the water samples. The main constituent of the underlying shale formation is $\mathrm{Na}$, and its associated formation water is of $\mathrm{Na}-\mathrm{K}-\mathrm{Cl}$ type [4].

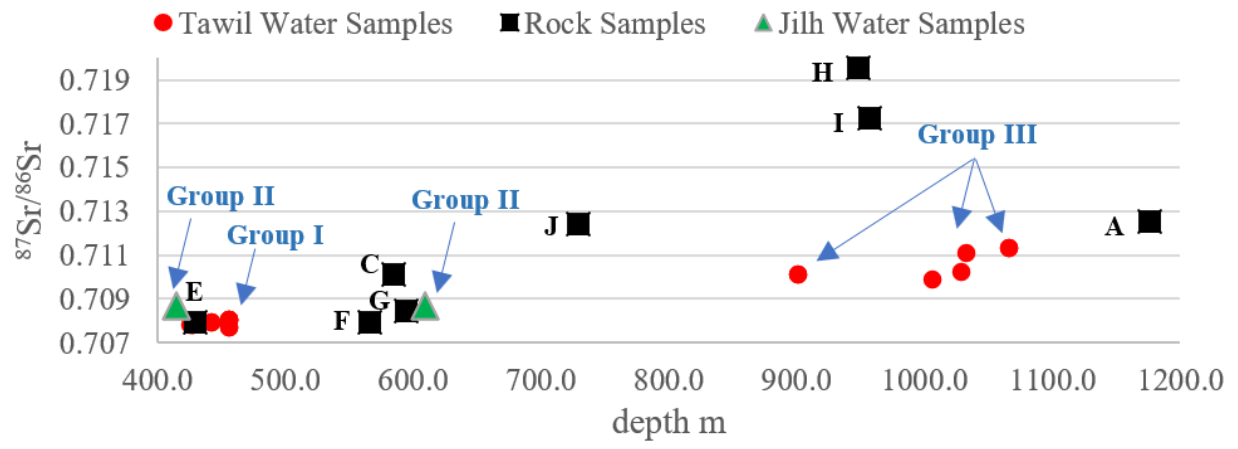

Fig. 3. ${ }^{87} \mathrm{Sr} /{ }^{86} \mathrm{Sr}$ for groundwater and rock samples vs. depth.

Figure 3 illustrates that ${ }^{87} \mathrm{Sr} /{ }^{86} \mathrm{Sr}$ increases with depth, especially in the water samples, and this correlation was $t$-tested to be significant at the $99 \%$ probability. The ${ }^{87} \mathrm{Sr} /{ }^{86} \mathrm{Sr}$ of Tawil rock samples (boreholes E, F, and $\mathrm{G}$, with ${ }^{87} \mathrm{Sr} /{ }^{86} \mathrm{Sr}$ of $0.707987,0.707930$, and 0.708428 , respectively) is inherited by surrounding groundwater samples with lowest ${ }^{87} \mathrm{Sr} /{ }^{86} \mathrm{Sr}(0.707673-0.708014)$ north of Wadi Sirhan Basin (Fig. 1). Note that $\mathrm{Sr}$ was extracted from the oxide phase of $\mathrm{E}$ and $\mathrm{G}$ rock samples. Aquifer rock sample A from deeper section $(1176 \mathrm{~m}$ ) influences the deeper groundwater (Group III), showing radiogenic ${ }^{87} \mathrm{Sr} /{ }^{86} \mathrm{Sr}$ values. In contrast, east of the Devonian aquifer outcrop (Fig. 1), the ${ }^{87} \mathrm{Sr} /{ }^{86} \mathrm{Sr}$ of cutting samples from borehole $\mathrm{J}(0.712406)$ is not reflected in the surrounding water well samples $\left({ }^{87} \mathrm{Sr} /{ }^{86} \mathrm{Sr}\right.$ of 0.708611 and 0.708648$)$. The aquifer rock sample with $\mathrm{Sr}$ extracted from the residual phase $\left({ }^{87} \mathrm{Sr} /{ }^{86} \mathrm{Sr}\right.$ of 0.759395$)$ is not inherited by the groundwater, indicating lack of groundwater interaction with the residual phase of the host rock.

\section{Conclusions}

The ion exchange between $\mathrm{Ca}^{2+}$ and $\mathrm{Na}^{+}$reflects the replacement of primary gypsiferous waters by Na-rich waters. Lower section of Tawil aquifer displays radiogenic ${ }^{87} \mathrm{Sr} /{ }^{86} \mathrm{Sr}$ (0.712477) compared to the upper section (0.707930-0.708428). The oxide phase of the host rock influences the chemical composition of groundwater through water-rock interaction, as groundwater from Tawil aquifer inherits Sr extracted from the oxide phase of the host rock, which reflects the presence of reducing condition north of Wadi Sirhan Basin.

\section{References}

1. UN-ESCWA and BGR, Inv. of Shar. Wat. Res. in West Asia, (2013)

2. A. Tessier, P. Campbell, M. Bisson, Analy. Chem., 51, 7 (1979)

3. J. D. Hem, USGS, 2254, 104-105 (1985)

4. P. Birkle, Geofluids, 16, 3 (2016) 